\title{
Regular and Temporary Employees in Project Organized Business Pay Different Attention to Preconditions for Learning
}

\author{
Gunnar AUGUSTSSON, Maria RASMUSSON \\ Mid Sweden University, The Department of Education, 85170 Sundsvall, Sweden, \\ gunnar.augustsson@miun.se, maria.rasmusson@miun.se
}

\begin{abstract}
Background and purpose: The purpose is to investigate whether regular and temporary staff differ in their perceptions of preconditions for learning and if there are some qualitative aspects that can be considered particularly significant in these differences.

Design/Methodology/Approach: The approach consists of a case study based on both quantitative and qualitative data collected via an online questionnaire and individual interviews.

Results: The paper question the understanding of the organization as a singular and more or less cohesive unit. On an organizational level, the project owner who hires staff does not care for competence transfer between regulars and temps, or between different groups of staff. At the individual level, temps are more focused on their specific task compared to regulars. Regulars' seems to safeguarding a community or an organizational perspective, while temps are looking for their own good.

Conclusions: There is a risk that one social unit differs, in attention payed to preconditions for learning, from another, when an organization use temporary staff. Therefore, the scientific value of this paper is that using temps may result in or be a consequence of a fragmented organization. The findings show no competence transfer in projects with both temps and regulars, and the project owner takes no active responsibility for human resource planning in terms of competence transfer between different groups of staff. The implications underline that long-term efficiency and rationality in an organization does not always have priority over organizational affiliation even with the hiring of expertise. When this happens, it may lead to a fragmented personnel group that is divided in thinkers/organizers and, performers/doers. When this happens, important practical skills fall outside of the organization, which in a metaphorical sense means that the hand is separated from the brain. Therefore, organizations with temporary staff need to plan for how to enable competence transfer between temporary and regular staff.
\end{abstract}

Keywords: competence transfer; inter-organization; project organization; temporary work

\section{Introduction}

As more and more organizations make use of temporary staff, complex versions of inter-organizational relationships will become more important to study. This paper deals with an inter-organizational based project organization and regular and temporary staff's (temps') learning in terms of interaction, knowledge, and motivations. Precon- ditions for learning may be related to a local organizational context with either positive or negative significance.

A special form of learning is associated with the concept of competence. Competence refers to "an individual's potential to act in relation to a certain task, situation or context," that is, "to successfully... do a job, including the ability to identify, exploit, and, if possible, extend the space of interpretation, action and measurement that the work tasks offer" (Ellström, 1992, p. 21). Based on the

Received: January 5, 2018; revised: April 23, 2018; accepted: May 15, 2018 
concept of competence, it is valuable to study the nature of learning preconditions that may be associated with temps. Such a study may partly contribute to research on learning in project organizations (Packendorff, 1995) and partly illustrate the learning in terms of human resource planning as competence transfer between the regular staff and temps.

In the present paper competence transfer is equated with the "process through which organizational actorsteams, units, or organizations - exchange, receive, and are influenced by the experience and knowledge" (van Wijk, Jansen, \& Lyle, 2008, p. 832). The authors show that work organizations are dependent on adding new knowledge, both for efficiency and for business development. Such knowledge transfer is a process where "one social unit learns from or is affected by the experience of another unit" (Argote \& Fahrenkopf, 2016, p. 146). The social units in this case is personnel from a temporary agency or who have their own firm and is hired of a governmental organization with its regular personnel. The hired personnel are often persons with specific individual competences that are needed in the governmental organization.

Individual competences should not be confused with knowledge. IPMA (2015) sees individual competence as the application of knowledge, skills and ability in order to achieve a task. "Knowledge is the collection of information and experience that an individual possesses. ... Skills are specific technical capabilities that enable an individual to perform a task. ... Ability is the effective delivery of knowledge and skills in a given context" (p. 15). The difference between IPMA's definition of knowledge, skills and ability is that knowledge of, for example, a flow chart is about knowing what such a chart is, skills make it possible to create a separate chart and with ability it becomes possible to use the created chart within the framework of a project.

The study's specific level of analysis is the transfer of individual competences associated with or not associated with temps.

The purpose of this study is to analyze learning preconditions for personnel from different employers within a project organization. Two research questions will be answered. 1) Do regulars and temps in an inter-organizational based project organization differ in their perceptions of their learning preconditions in the project? If so, in what way? and 2) Are there any qualitative aspects in an inter-organizational based project organization that can be considered as particularly significant for the cooperation between regulars and temps? If so, which are they?

\section{Competence Transfer in an Inter- organizational Context}

Research on improving management efficiency of knowledge and expertise within organizations often assumes that competence transfer is desirable (Bartsch, Eber, \& Maurer, 2013; Carlsson, 2003; Chen, Tong, \& Ngai, 2007; Ragab \& Arisha, 2013; Wagner \& Buko, 2005). In this paper, although desirable, we show that this is not always the case. There seems to be obstacles in competence transfer in knowledge-intensive organizations that hire qualified experts.

Song, Almeida, and Wu (2003) examined "the conditions under which mobility is most likely to facilitate interfirm knowledge transfer through learning-by-hiring" ( $p$. 361). One of their findings are relevant in this context and that is that the motives for hiring experienced engineers is when a firm "lack well-defined technological trajectories" (p. 361).

Huckman and Pisano (2006) studied "whether specific worker-firm combinations yield higher performance than others" (p. 475), and they found that "surgeon performance is not fully portable across organizations" (p. 484). They argue that this finding may refer to the surgeons familiarity with the actual organizational context. "[T]his relationship ... reflects the productive benefits associated with a surgeon's familiarity with critical assets of the hospital organization" (p. 485).

Other research shows that the project owner has a clear responsibility for knowledge transfer between project and parent organization (Bakker, Cambre, Korlaar, \& Raab, 2011, p. 502). Further, research on project organizations reported tensions between project and parent organization (Scarbrough et al., 2004), social aspects (Bartsch et al., 2013), gender (Cartwright \& Gale, 1995; Gale \& Cartwright, 1995; Lindgren \& Packendorff, 2006) and inter-project learning (Prencipe \& Tell, 2001). The analysis level of our study covers differences in regulars and temps perceptions of preconditions for learning within an interorganizational project organization.

This paper is based on data from a study of a Swedish government agency, the Swedish Transport Administration (STA), which is responsible

for long-term planning of the transport system for road, rail, sea and air operations and for the construction, operation and maintenance of state roads and railways. STA also examines questions about state subsidies to Swedish shipping industry and promotes accessibility in public passenger traffic by procurement of contracts. (STA, 2015a)

The quote shows that the STA is a complex organization with different business areas. The STA is a Swedish administrative authority, which began its operations on April 1, 2010. With the authoritie's arrival, several authorities 
within the Swedish transport system gathered in one authority. We estimate that STA's maturity level corresponds to number 3 in Mullaly's and Thomas' (2010) assessed levels of project management maturity. There is a complete project management process in place that seems to be consistently utilized on all projects within the organization, but we also estimate that something is missing because there is different access to information between regular and temporary employees.

The fields of activities involved in this study are primarily temporary project organizations developed and phased out based on their tasks (Turner \& Müller, 2003). The study includes staff working on state roads and railways. This means that the organizational context consists of various more or less cohesive units, that is, it is not obvious to consider the STA as a cohesive organization. Instead, the STA is a project-based organization with both regular and temp staff.

The implication of the fact that the STA represents a project organizational context with both regulars and temps is that the STA is about both temporary organization and temporary employment (Bakker, 2010). First, each individual project within the STA is temporary in terms of limitations in "time, task, team and transition" (Lundin \& Söderholm, 1995, p. 439) and context (Bakker, 2010). Moreover, the STA is characterized by a high degree of "action-based entrepreneurialism, fragmentation of a commitment-building, planned isolation and institutionalized termination" (Lundin \& Söderholm, 1995, p. 445). Secondly, the STA differs from previous research on project organizations because the STA, to a high degree, often, but not always, bases projects on temps, from project managers over construction managers to administrators. This paper contributes to the existing literature by analyzing the organizing of transfer or lack of transfer of competence over time and between teams within an inter-organizational based project organization with regular and temporary employees.

\section{Organizational Backgrounds and Dimensions of Learning}

We have combined Martin's (2002) three versions of organization with Illeris $(2007,2011)$ three dimensions of learning. These two theoretical views will first be described separately and thereafter in combination. Martin (2002) describes three versions of organizational culture: integration, differentiation, and fragmentation. We will consider the organization as a background for individual projects that can be referred to when invoking various manifestations of participation that indicate preconditions for learning.

Integration, the first of three organizational backgrounds, has to do with the assumption that an organiza- tion is characterized by consistency, that is, an organization-wide consensus and clarity. In this context, it means that the conditions for learning, that is, the increased "level of complexity... that is relevant in a given situation" (Illeris, 2007 , p. 67) are related to one organizational background consisting of one or more organizational units. Differentiation also implies one organizational background consisting of overlapping and embedded units coexisting in the form of opinions that are in harmony, conflict, or indifference to one another. Fragmentation assumes that claims of clarity, consistency, and consensus are idealized simplifications that fail to capture the complexity of an organization. Instead of banning ambiguity, as integration does, or consigning ambiguities to the gaps between different organizational backgrounds, as differentiation, the fragmentation perspective considers ambiguity as a characteristic trait for organizational cultures. In this case, fragmentation makes it possible to convey an understanding of the inter-organizational preconditions for the current learning, that it exists in such a complex organizational environment with personnel from different organization, which cannot be described in a straightforward manner.

Although most of the studies, according to Martin (2002), use only one of the three perspectives, she believes that all organizations contain elements that are consistent with all three perspectives. In our case, if Martin's theory is true, this means that if the STA is studied deeply enough, the preconditions for unambiguous learning will manifest themselves in the form of a more or less organization-wide consensus, consistency, and clarity (integration). Meanwhile, other types of conditions for learning will be blended in different and ambiguous perceptions (differentiation). Finally, some conditions for learning will be difficult to interpret in a state of constant change, and therefore will generate multiple, but hopefully still reasonable, interpretations (fragmentation). The primary merit of the use of Martin's concepts is that they make it possible to empirically question the understanding of the organization as a singular and more or less cohesive unit.

Three key dimensions of learning will be related to the abovementioned organizational backgrounds (Illeris, 2007, 2009): Social Interaction, which refers to action, communication, and collaboration; Content, which is characterized by knowledge, understanding, and skills; and Incentive, associated with motivation, emotion, and will.

The Social Interaction dimension has to do with situated learning, that is, a social and context-bound learning (Illeris, 2007, p. 150). This learning can be linked to "perception, communication, experience, imitation, activity or participation" (p. 150). The important part of this learning is the possibility for "active involvement and codetermination, involvement in subjective relevant problematics, critical reflection and reflexivity, and social responsibility" (p. 150). Perception consists of impulses that affect learning processes (Illeris, 2011). Communication is associated 
with transmission of certain messages or certain information. Experience is linked to a certain type of positive or negative learning in a particular situation. Imitation has to do with someone imitating someone else in the performance of a particular task. Activity emphasizes learning based on the perspective of the learner in the context of a commitment in goal-oriented activities (p. 26). Participation, finally, refers to learning that expresses "in a community of practice for an extended period of time" (p. 26). The meaning of the social interaction dimension is that social interaction includes interactions from "unmediated sense impressions" (p. 25) to long-term collaborations.

Within the Content dimension, learning can be acquired in four different ways: cumulatively, assimilatively, accommodatively and transformatively (Illeris, 2011). The cumulative learning is associated with a mechanical learning without any advanced thought and contextuality. For example, it may be about memorizing a PIN code. Assimilative learning corresponds to learning about something specific in relation to a particular context. The accommodative learning is characterized by a breakdown of something already known and a creative and largely independent restructuring of the disintegrated. The transformational learning, ultimately, involves a meta-learning in multiple areas, i.e. "decomposition of several schemes in a coherent process and their restructuring into a new coherent understanding and experience in relation to one or more significant areas of life" (Illeris, 2011, p. 18). This means that the content dimension extends from an automatic and context-free learning to an overall learning from different perspectives.

The Incentive dimension is connected to "the extent and nature of the mental energy invested in learning, that is, the motivation, the emotions and the will of the individual mobilizes in a learning situation or in a learning process" (Illeris, 2007, p. 119). Illeris (2007) describes the result as motivational, emotional, and volitional patterns. An important aspect is that the challenges in learning that the individual faces should not be overpowering but instead be tuned in relation to interests and preconditions. In other words, a person's learning depends on whether his motivation is higher or lower and if the will is strong or weak. Both motivation and will form the basis for whether the person is open to a particular learning or if he is opposed to it (Illeris, 2011).

These three dimensions, Social interaction, Content and Incentive is connected to competence through their qualities: the learner's personal sociability, functionality, and sensivity (Illeris, 2011). In combination they make it possible for the learner to build up his sociality, to "construct meaning and the ability to deal with the challenges of practical life", and "to secure the continuous mental balance" (Illeris, 2011, p. 62).

We consider learning a meaning-making process, partly in line with Jonassen and Land (2012) and partly in terms of Weick's (1995) unit of analysis: "cue + relationship + frame". (p. 110). The unit of analysis involves an empirical indication of preconditions for learning (cue) that is set against its (relationship) background (frame). The logic in this context is that manifestations in terms of Social Interaction, Content, and Incentive give rise to a particular type of mental associations (interpretations) when they are related to a particular organizational background, and it is these preconditions for learning that are analyzed in the present paper (see Table 1). Thus, the aim is to investigate whether regular and temporary staff differ in their perceptions of preconditions for learning and if there are some qualitative aspects that can be considered particularly significant in these differences.

Table 1 shows how Illeris's (2007, 2011) learning dimensions are combined with Martin's (2002) versions of organizational culture, here applied as organizational backgrounds. The learning dimensions highlight the situated, the conscious, and the proactive nature, while the organizational backgrounds distinguish the unambiguous, ambiguous, and split from one another.

Table 1: Analysis Model for the Relationship Between the Learning Preconditions and Organizational Backgrounds

\begin{tabular}{|l|l|l|l|}
\hline $\begin{array}{l}\text { Learning/organizational } \\
\text { background }\end{array}$ & Social Interaction & Content & Incentive \\
\hline Integration & $\begin{array}{l}\text { 1. Unambiguous situated/ } \\
\text { context bounded learning }\end{array}$ & $\begin{array}{l}\text { 2. Unambiguous awareness } \\
\text { of its personal and business } \\
\text { environment }\end{array}$ & $\begin{array}{l}\text { 3. Unambiguous motivation, } \\
\text { emotion, and desire }\end{array}$ \\
\hline Differentiation & $\begin{array}{l}\text { 4. Ambiguous situated/con- } \\
\text { text-bounded learning }\end{array}$ & $\begin{array}{l}\text { 5. Ambiguous awareness } \\
\text { of its personal and business } \\
\text { environment }\end{array}$ & $\begin{array}{l}\text { 6. Ambiguous motivation, } \\
\text { emotion, and desire }\end{array}$ \\
\hline Fragmentation & $\begin{array}{l}\text { 7. Split situated/con- } \\
\text { text-bounded learning }\end{array}$ & $\begin{array}{l}\text { personal and business envi- } \\
\text { ronment }\end{array}$ & $\begin{array}{l}\text { 9. Split motivation, emotion, } \\
\text { and desire }\end{array}$ \\
\hline
\end{tabular}




\section{Method}

This is a case study of an organization that holds a number of business areas (Yin, 1994). The case is complex, and its responsibilities include long-term planning of the transportation system for all modes of transport; construction, operation, and maintenance of state roads and railways; implementation of theoretical and practical tests for driver's licenses and taxi licenses; theoretical tests for licensing and professional driving skills; and basic availability of interregional public passenger transport through procurement of traffic (STA, 2015b). This case concerned the construction, operation, and maintenance of state roads and railways.

The data collection was based on both quantitative and qualitative data collected via an online questionnaire and individual interviews. The reason for using mixed methods was to elucidate the complexity of renting personnel to a project organization (see Mertens, 2012; Ercikan \& Roth, 2006).

\subsection{Description and Analysis of Quantitative Data}

The questionnaire used has been designed in collaboration by three project members and one of the authors of this paper. One of these members compiled and distributed the web link to the questionnaire to a key person within the STA, who in turn, in March 2011, forwarded the link in the organization.

The survey was sent to all staff groups linked to the STA: regular employees, agency workers, and temporary self-employed workers (F-tax). In total, the survey was distributed to 2,135 people, and the response rate was $51.3 \%$ (after two reminders). The response rate is due to a number of people dropping out of the employment or assignment; in addition, a number of staff did not respond to the questionnaire. The response rate for the groups, regular and temporary staff, was equivalent and thus, no post stratification or weights were considered necessary.

The respondents were between 18 and 71 years old, with a mean age of 47 years. A regular was defined as a person who responded that they were employed by the STA, and temps were those who answered that they were rented from temporary agencies, consulting firms, private companies, or other professionals. There were a total of 1,095 respondents, and 1,044 answered the question whether they were regulars or temps (51 missing). Two of these people did not specify their gender. The sample used in the analyses, which includes those who answered the questions about their position and gender, was 1,042 (see Table 2). The sample in the present analysis was not an independent random sample, and thus, the significance tests should be interpreted with caution. However, due to the large sample size, it can be assumed to give a reliable understanding of the workforce at the STA.

Table 2 shows that the analyses are based on 1,042 people and that $32 \%$ of these were women with an average age of 42 years. In all, 52\% were regulars. This means that the questionnaire sample included a good proportion of temps (48\%) and a reasonably high proportion of women $(32 \%)$.

The collected survey data were statistically processed in SPSS. The analysis was preceded by the construction of indices, and the reliability of these indices was estimated. Thereafter logistic regression analysis was performed, using the three dimensions as predictors, in order to evaluate how much the different dimensions contributed to the odds of being an employee or a temp when gender, age, income, and education were accounted for. This is a well-suited method for predicting group membership, in this case regulars and temps. The models are stipulated with an outset in Illeris' (2007, 2011) learning dimensions and the association these dimensions are hypothesized to have with the two forms of employment, regular and temp, to contribute to the purpose of the study. The degree of model fit is estimated with the data collected in the present project.

The survey questions dealt with background information (e.g., age, education, and sex) as well as a number of areas such as working conditions, career development, and the perceived social climate of the workplace. A total of 35 themes were covered in the survey, and each theme included one to 12 questions.

In Table 3, 17 people have fallen away from the analysis compared with Table 2. Table 3 shows that the women who answered the survey are in the minority (33\%), and that especially applies to the professions of engineers (19\%), technicians/construction managers (13\%), and project managers (27\%).

Table 2: Personnel Group and Age Divided by Sex

\begin{tabular}{|c|c|c|}
\hline & Female (percent) & Male (percent) \\
\hline Number & $338(32 \%)$ & $704(68 \%)$ \\
\hline Regular & $197(37 \%)$ & $342(63 \%)$ \\
\hline Temp & $141(28 \%)$ & $362(72 \%)$ \\
\hline Average age & 42 & 50 \\
\hline
\end{tabular}


Table 3: Respondents Divided by Occupation and Sex

\begin{tabular}{|c|c|c|c|c|}
\hline Occupation & $\mathbf{n}$ & Percent & $\begin{array}{c}\mathbf{n} \text { Women } \\
\text { (percent) }\end{array}$ & $\begin{array}{c}\mathbf{n} \text { Men } \\
\text { (percent) }\end{array}$ \\
\hline Engineers & 357 & 34.8 & $70(19 \%)$ & $287(81 \%)$ \\
\hline Quality/data & 66 & 6.4 & $20(30 \%)$ & $46(70 \%)$ \\
\hline Environment & 68 & 6.6 & $37(54 \%)$ & $31(46 \%)$ \\
\hline Technicians/construction managers & 118 & 11.5 & $15(13 \%)$ & $103(87 \%)$ \\
\hline Administrator/assistant & 92 & 9 & $85(92 \%)$ & $7(8 \%)$ \\
\hline manager & 20 & 2 & $3(15 \%)$ & $17(85 \%)$ \\
\hline Economist/purchaser & 145 & 14.1 & $60(41 \%)$ & $85(59 \%)$ \\
\hline Project managers & 154 & 15 & $42(27 \%)$ & $112(73 \%)$ \\
\hline Other & 5 & .48 & $2(40 \%)$ & $3(60 \%)$ \\
\hline Sum & $\mathbf{1 , 0 2 5}$ & $\mathbf{9 9 . 8 8}$ & $\mathbf{3 3 4}(\mathbf{3 3 \% )}$ & $\mathbf{6 9 1}(\mathbf{6 7 \%})$ \\
\hline
\end{tabular}

Table 4: Items Included in the Three Dimensions of Learning Preconditions Note. The questionnaire was developed specifically for this project

\begin{tabular}{|c|c|c|}
\hline Dimensions & Items & Variable value \\
\hline \multirow{5}{*}{$\begin{array}{c}\text { Social } \\
\text { Interaction }\end{array}$} & 1. Do you think your boss cares about you as a person? & \multirow{3}{*}{$\begin{array}{l}\text { No, not at all; No, } \\
\text { hardly; Yes, to some } \\
\text { extent; Yes, greatly }\end{array}$} \\
\hline & 2. Do you think your boss encourages and supports you? & \\
\hline & $\begin{array}{l}\text { 3. Do you think your boss will give you clear instructions on how the work } \\
\text { should be carried out? }\end{array}$ & \\
\hline & $\begin{array}{l}\text { 4. At my current workplace, cooperation does not work in a way that suits the } \\
\text { performance of my duties. }\end{array}$ & \multirow{5}{*}{$\begin{array}{l}\text { Strongly disagree; } \\
\text { Tend to disagree; } \\
\text { Neutral; Tend to agree; } \\
\text { Agree }\end{array}$} \\
\hline & $\begin{array}{l}\text { 5. At my current workplace, it is difficult to know whom you can and cannot } \\
\text { rwork with. }\end{array}$ & \\
\hline \multirow{7}{*}{ Content } & $\begin{array}{l}\text { 6. Through the work at my current job, I have learned skills that are sought } \\
\text { after in today's job market. }\end{array}$ & \\
\hline & $\begin{array}{l}\text { 7. I feel that I have developed as a person through my work at my current } \\
\text { workplace. }\end{array}$ & \\
\hline & 8. There are good possibilities for development at my current workplace. & \\
\hline & $\begin{array}{l}\text { 9. Do you get information from the people working at this workplace that is of } \\
\text { importance for your work? }\end{array}$ & \multirow{2}{*}{$\begin{array}{l}\text { Very rarely or never; } \\
\text { Quite rarely; Some- } \\
\text { times; Quite often; } \\
\text { Very often }\end{array}$} \\
\hline & 10. Do you get tips or advice from colleagues who do the work easier? & \\
\hline & 11. I have a lot of freedom to decide how I will perform my duties. & \multirow{6}{*}{$\begin{array}{l}\text { Strongly disagree; } \\
\text { Tend to disagree; } \\
\text { Neutral; Tend to agree; } \\
\text { Agree }\end{array}$} \\
\hline & $\begin{array}{l}\text { 12. At my current workplace, a lot of my own thinking is required to perform } \\
\text { my duties. }\end{array}$ & \\
\hline \multirow{4}{*}{ Incentive } & 13. If I could, I would change my current workplace with someone else. & \\
\hline & 14. I do not feel comfortable with my current career choice. & \\
\hline & $\begin{array}{l}\text { 15. The more I learn about my work tasks at my current workplace, the more } \\
\text { fun it is to go to work. }\end{array}$ & \\
\hline & $\begin{array}{l}\text { 16. At my current workplace, my skills are appreciated in a way that I think } \\
\text { they deserve. }\end{array}$ & \\
\hline
\end{tabular}


Analyses of quantitative data include a total of 16 items on Social Interaction (5), Content (7), and Incentive (4).

Table 4 shows the items and values of the variables included in the different dimensions of learning preconditions. The term "learning preconditions" means that we have not studied learning per se but the respondents' perceptions of their opportunities for learning, also denoted as competence and competence transfer. The answers to the items were converted to indices by adding the variables chosen for the index. First, each variable was converted to a common scale ranging from zero to five. For example, the first three items in the dimension Social Interaction had four response alternatives coded from one to four (see Table 4). These were rescaled to zero to five as all the other items. The rescaling ensured that each item in the dimension contributes equally to the variance in that dimension. The index Social interaction ranges from 0 to 25, Content from 0 to 35 and Incentive from 0 to 20 .

The variables are coded so that the higher the value, the more Social Interaction, Content, or Incentive. This means that if the average is higher, one has responded in a positive direction. For a negatively charged item such as No. 5 there has reversed encoded so that the original low value will be high and vice versa.

Based on the indices, an analysis of the differences between regulars and temps was carried out and a more detailed analysis of the dimensions based on a breakdown of the respondents in men and women was conducted.

\subsection{Qualitative Data-Interpretation of Contextual Circumstances for Learning}

Collected qualitative data were based on a sample from the same population (STA staff) as the quantitative, but the interviews were, to a larger degree, conducted from an organizational (contextual) perspective and in a more unconstrained and flexible manner than possible in a questionnaire. We could not influence the selection of the 21 interviewees, who were selected by staff within the STA. Of these, seven were regular, six were temp project managers, six were temp construction managers, one was a temp expert, and one was a temp administrator. Temps and regulars often work together in groups, but usually with complementary duties. In most cases, people in both categories have experiences that make it possible to assume that they possess corresponding competence. This sample consisted of 18 men and three women, that is, $14 \%$ women. Women have the code numbers 22,38 , and 95 .

The primary purpose of the interview study was to study the regulars' and temps' ideas of the preconditions for learning in terms of competence and competence transfer. The concepts, competence and competence transfer, are most likely perceived in different ways among the in- terviewees and this was not seen as a validity issue in the present study as the interviews covered preconditions for learning that make competence transfer possible. Thus, the interviews were targeted to capture the mechanisms behind the concept of competence transfer. During the analysis of qualitative data, a reference was repeated in the interviewees' utterances that revealed a more complex organization than we originally expected. It is this complexity that is reported in terms of Integrated, Differentiated, and Fragmented organizational backgrounds, and this complexity is the qualitative data's unique contribution to the study in comparison with the quantitative data.

The qualitative data presented in this paper are based on a total of 75 utterances, of which $30(40 \%)$ came from women. The analysis has been carried out in four steps. The first step was an unbiased reading of the transcribed interviews, regardless of the conceptual dimensions of Table 4. Thereafter, a systematic coding of the interviews was made based on the conceptual dimensions. After that, selected observations were sorted in different patterns, and during that sorting, the organizational qualities were discovered, which in a fourth stage were dimensionalized in terms of Integration, Differentiation, and Fragmentation. It is the results of these four analytical steps that are reported in this study.

The interviews were coded to make it possible to see the variations in the following categories: individual number; project manager $(\mathrm{PM})$, construction manager $(\mathrm{CM})$, expert (Exp), or administrator (Adm); employed (Emp) or temporary worker (Temp); and assignment connected to road (Road) or railway (Rail). The code "38, PM, Emp, Road/Rail" means the interview was conducted with individual No. 38, a project manager, employed by STA, and connected to both road and railway construction.

\subsection{Reliability and Validity}

As mentioned in the initial parts, the analysis is, among others, based on Illeris's $(2007,2009,2011)$ theory that includes the dimensions of learning Social Interaction, Content, and Incentive. Based on the survey items, indices were created for each learning dimension (see Table 4). The reliability of the indices, estimated with Cronbach's alpha, ranged from 0.6 to 0.7 (see Table 5). Cronbach's alpha is an estimate of how well the items included in each index measures the same phenomenon (Pedhazur \& Pedhazur Schmelkin, 1991) and the rule of thumb is to accept indices with alpha larger than 0.7. However, generally, a larger number of items gives a larger alpha and as the index Incentive only have four items an alpha estimate of 0.63 is considered acceptable (see e.g. Lowenthal, 2004).

Reliability and validity in the analysis of qualitative data were carried out by the authors by a) comparisons of analyses and interpretations of the same data with each other (internal reliability) and b) in collaboration, test- 
Table 5: Reliability Test of the Four Indices Created

\begin{tabular}{|c|c|c|}
\hline Index & Number of survey questions & Cronbach's alpha \\
\hline Social Interaction & 5 & 0.74 \\
\hline Content & 7 & 0.70 \\
\hline Incentive & 4 & 0.63 \\
\hline
\end{tabular}

Table 6: Summary of logistic regression analysis for variables predicting regulars and temps, ${ }^{*} p<.05$ Note. Cox \& Snell's $R 2=.015$, Nagelkerke's $R 2=.02, n=899$.

\begin{tabular}{|c|c|c|c|c|c|}
\hline Predictor & B & SE B & Wald's chi ${ }^{2}$ & Df & ${\text { Odds ratio }\left(\mathrm{e}^{\mathrm{B}}\right)}$ \\
\hline Social Interaction & $-0.046^{*}$ & 0.018 & 6.3 & 1 & 0.955 \\
\hline Content & $0.056^{*}$ & 0.022 & 6.9 & 1 & 1.058 \\
\hline Incentive & -0.044 & 0.024 & 3.2 & 1 & 0.957 \\
\hline Constant & 0.276 & 0.452 & 0.4 & & 1.318 \\
\hline$\chi 2$ & & 12.220 & & & \\
\hline $\mathrm{df}$ & & 3 & & & \\
\hline
\end{tabular}

ed collected data against the dimensions of learning and organizational backgrounds (internal validity). We have made no attempt to find out if some of the respondents who answered the survey were included in the interviews.

\section{Results}

Below are the quantitative and the qualitative data analyses reported. The reason for the use of quantitative data is to present general results, and the purpose of using qualitative data is to present specific qualities in relation to the interviewees' understanding of competence and competence transfer and various organizational backgrounds.

\subsection{Quantitative Data-Attitudes Toward Learning Conditions}

In this section, the results from the logistic regression analyses of the quantitative data are presented, based on the three dimensions of Social Interaction, Content, and Incentive.

The first step in the analysis was to test a model with the three learning dimensions as independent variables. The model was statistically significant, indicating that the predictors distinguished between regulars and temps (chi square $=12.22, \mathrm{p}=.007$ with $\mathrm{df}=3$ ). The Wald criterion demonstrated that the Content dimension and the Social interaction dimensions made significant contributions to the prediction. The Incentive dimension was not a significant predictor. A person has a 55 per cent probability of belonging to the regulars if reporting a maximum on all three dimensions (see Table 6):
Logit $(\ln 0)=0,276$ (=constant) $-0,046 * 25$ (social interaction $=25)+0,056 * 35$ (content $=35)-0,044 * 20$ (incentive $=20$ ). The antilog is calculated and thereafter the probability is computed $(\mathrm{p}=\mathrm{o} /(1+\mathrm{o}))$. Table 6 shows that the odds for being a regular decrease with .05 if the variable Social interaction increases with 1 . The odds for being a regular increase with .06 for every one-unit increase in the Content dimension. The Incentive dimension is not statistically significantly different from zero.

In a second step, a number of control variables were added, namely gender, age, education, and income. A test of the full model against a constant only model was statistically significant, indicating that the predictors as a set, reliably distinguished between regulars and temps (chi square $=60.6, p=.000$ with $\mathrm{df}=7$ ). The Wald criterion demonstrated that the Content, Social dimension, and the Incentive dimension made significant contributions to the prediction when gender, age, education, and income were taken into account. The odds for a person to belong to the group regulars decreases with 0.05 for every one-unit increase in the Social interaction dimension as well as the Incentive dimension. The odds of being a regular increase with 0.06 for every one-unit increase in the Content dimension. A longer education contributes most of all variables with increased odds of being a regular (0.4).

The results suggest that, with human resource planning in mind, the regulars and temps differ in their perceptions of learning conditions regarding these dimensions. In addition, it can be noted that gender and income were not significant predictors for regulars and temps. 
Table 7: Summary of logistic regression analysis for variables predicting regular and temps, controlling for background variables, *p $<.05$

Note. Cox \& Snell's $\mathrm{R}^{2}=.074$, Nagelkerke's $\mathrm{R}^{2}=0.10, \mathrm{n}=899$.

\begin{tabular}{|c|c|c|c|c|c|}
\hline Predictor & B & SE B & $\begin{array}{c}\text { Wald's } \\
\text { chi }^{2}\end{array}$ & Df & Odds ratio $\left(\mathrm{e}^{\mathrm{B}}\right)$ \\
\hline Social Interaction & $-0.046^{*}$ & 0.019 & 5.5 & 1 & 0.955 \\
\hline Content & $0.063^{*}$ & 0.023 & 7.3 & 1 & 1.065 \\
\hline Incentive & $-0.054^{*}$ & 0.026 & 4.4 & 1 & 0.947 \\
\hline Gender & 0.131 & 0.173 & 0.6 & 1 & 1.140 \\
\hline Age & $0.035^{*}$ & 0.009 & 16.8 & 1 & 1.036 \\
\hline Education & $0.401^{*}$ & 0.078 & 26.2 & 1 & 1.494 \\
\hline Income & 0.182 & 0.123 & 2.2 & 1 & 1.200 \\
\hline Constant & $-3.682^{*}$ & 0.763 & 23.3 & & 0.025 \\
\hline$\chi 2$ & & 60.6 & & & \\
\hline df & & 7 & & & \\
\hline
\end{tabular}

\subsection{Qualitative Data-Interpretation of Contextual Circumstances for Learning}

This section is about the learning dimensions Social Interaction, Content, and Incentive in relation to the organizational backgrounds Integration, Differentiation, and Fragmentation (see Table 1). The number before each textual subheading refers to a cell in Table 1 . After each heading are the number of utterances that belong to the current cell reported, how many utterances came from women (wo), and finally how many interviewees (IP) commented.

\subsection{Social Interaction}

The Social Interaction dimension is marked by the staff members' wish to work together toward common goals based on fairly shared and complementary bases.

\subsubsection{Integration (10 utterances [9 wo], 3 IP).}

Ideas of the common basis for knowledge emerge in the following quote:

Whoever hires temps should say that when you are here with us, then you get to share with you. And at the same time, if you are unsure about something, you should go and ask. (38, PM, Emp, Road/Rail).

The above quotation emphasizes an expectation of social interaction from temps, which can be interpreted to support the results from the survey in Table 6 .

\subsubsection{Differentiation ( 9 utterances [5 wo] 4 IP).}

The above wish for social interaction in terms of integration needs to be supplemented with a differentiated form of social interaction. The differentiated form emphasizes the presence and needs of different but complementary conditions for different groups of staff:

Take the peaks with consultants. Then you have both (46, PM, Emp, Road).

This quote refers to a parent organization with undersized regular staff that, when necessary, is filled with temps. Differentiation may also provide support for the fact that the regulars' and temps' perceptions of social interactions differed in the questionnaire study (see Table 6).

\subsubsection{Fragmentation (12 utterances [4 wo], 6 IP).}

Social interaction is characterized by some kind of community or commonality of substance. The fragmented version may be interpreted as a negation of this. An regular project manager underlines the difference between temp and regular staff:

Sometimes, I notice that both our specialists and other departments... are not prepared to give service to a temp that calls and wants information or wants to order or something. Without that, there may be irritation: "Why does this temp call me and want a decision?" The project manager, the real project manager... should do that. (38, PM, Emp, Road/Rail). 
The quote above confirms the existence of a hierarchy between temps and regulars.

An important consequence of this is that the STA is

...very poor to absorb the temps' knowledge, in that they do not get to be on our team meetings... (22, PM, Emp, Rail).

Taken together, the above quotes about fragmentation explain perceived differences between regulars and temps. This may be a consequence of differentiation, that is, that regulars seem to be more privileged in terms of Social Interaction and thus are perceived to have something that many temps probably feel is lacking.

\subsection{Content}

Content is associated with knowledge and an awareness of both oneself and the immediate and broader context.

\subsubsection{Integration (12 utterances [1 wo], 8 IP).}

Integration emphasizes the need for knowledge and an awareness that seeks cohesion of various kinds. A temp project manager connects integration perspective with regulars:

There is a societal perspective that is stronger in regular staff than in temps (49, PM, Temp, Rail).

The quote shows that the regulars are perceived to represent a (integral) consciousness about a societal whole and not only the defined task, compared Bakker's (2010) "task-orientation" (p. 477).

The significance of this is developed below.

And then I don't understand why we do not have that in our own organization, which I would have been able to bring with me [the most experienced] and say, "These I want to have with me..." (96, PM, Emp, Road/Rail).

In the above quote, a regular project manager is questioning why there is not access to specific competence internally. Compare Bakker's (2010) "repeated collaboration" (p. 479) and Prencipe and Tell's (2001) "barriers to learning" (p. 1374). Between the lines, it is possible to deduce that the questioning comes from the difference between perceived security and insecurity in having or not having access to skilled regular staff.

\subsubsection{Differentiation (8 utterances [2 wo], 6 IP).}

The meaning of Differentiation is the existence of different suborganizational backgrounds in the context of an overarching organizational background. However, there are limits to the extent to which it should occur.

I want to have a lot more regular construction managers and project managers... We have so incredibly many temps, even among construction managers, where we think we lose skills. Then they step out of the projects... It's more about the next step, what you learn and what knowledge you leave with, and there is my firm belief that one should have more regulars. (92, PM, Emp, Road/Rail).

The above quote expresses a regular project manager's dissatisfaction with difficulties within the parent organization over time to keep and implicitly develop skills. Compare Bakker's (2010) "knowledge dispersing" (p. 477). The logic is that the more temps, the greater the risk that competence is lost from the parent organization. The above quotation confirms the need for a strategic limitation of differentiation in the STA.

\subsubsection{Fragmentation (12 utterances [6 wo], 7 IP).}

Fragmentation legitimizes the existence of ambiguity within an organization. This means that one cannot expect any kind of uniform consensus in knowledge and awareness. Instead, we must expect the existence of unforeseeable and disparate perceptions and understandings.

As a project manager, one is very lonely. One has their own project, the group. And then we need to talk more with each other and help each other. It worked really well as long as we sat together. But now... true, we still help each other, but it involves much longer routes, and when you come in here now, from the outside, it will be very much more difficult to find contacts and find who can help you. (22, PM, Emp, Rail).

The above quote from a regular project manager confirms that the STA's Content dimension can be perceived as fragmented. Also, compare with Table 7. Project manager is a lonely job and has over time come to be seen as increasingly isolated.

In this context, it is valuable to raise the question of whether the parent organization has difficulty obtaining access to relevant information? 
With experience feedback, if you had been working on a little more systematized way to make use of the experience that arises in the projects... The experience disappears out of [parent organization] so that it instead ends up with us temps. For me, this is an education. I rise in value every day I work here, and that value goes, of course, to me... Next time they want me in a project, I will cost more. (91, PM, Temp, Road).

The temp project manager's answer to the question before the quote above is a definite no! On the contrary, he asks for a systematic competence transfer from the parent organization's side. This despite the fact that he risks losing in it. Compare Bakker's (2010) "career capabilities" (p. 479).

\subsection{Incentive}

Incentive concerns the motivations, the emotions, and the will that the individual connects with learning.

\subsubsection{Integration (3 utterances [1 wo], 2 IP).}

In terms of Incentive to learn from an Integration perspective, this is attributed solely to regulars. A regular project manager is clear that "you do not have the same stability as if you are a regular" (22, PM, Emp, Rail). Regulars are perceived as more unambiguous and stable in what drives them compared to temps.

It is not in the mission, not the goal. Bang, we disregard it. We are going there (49, PM, Temp, Rail).

This quote shows that temps have a clear limit on what is included in the specified mission, thereby driving them, and what lies beyond the mission and driving force.

\subsubsection{Differentiation (2 utterances [0 wo], 1 IP).}

Differentiation is based on some form of organizational division or subdivision. It is therefore important to ask the question of which incentive may underlie the differentiation within the organization. The following brief excerpt from a verbal exchange about the STA between the interviewer (I) and interviewee (IP) can provide a tentative answer to this question:

It seems as though the STA retains the regulations but releases the technique and practice... (I)

Yes. (IP, 48, Exp, Temp, Rail).
From this verbal exchange, it is not only clear that there is a differentiation between rules, technology, and practice within the parent organization but also what the differentiation consists of. Knowledge of and insight into the regulatory framework are protected in the STA, while technology and practice can be released and, if need be, rented. If this is true, it means that the temp project manager has a primary responsibility for technology and practice, which could explain why the temps in the survey differ from the regulars in the dimensions of Social Interaction and Incentive (see Table 6).

\subsubsection{Fragmentation (7 utterances [2 wo], 5 IP).}

The presence of ambiguity means that a uniform consensus about learning preconditions is likely to be replaced with unforeseeable and incompatible interpretations and perceptions.

Present order can affect project managers' motifs at the planning stage.

Maybe you had planned differently. In some cases, you might even have chosen another solution if you had the right skills from the beginning. Because you may want to avoid procuring... In our case, I have construction managers in five different areas of expertise that often are four or five different people... And to procure five different construction managers very early when you just need a little bit, it is not easy either. (22, PM, Emp, Rail).

The quote shows the risk of developing ambivalence toward whether to procure competences temporarily or not. This can be seen as a clear need for continuity of immediate access to certain competences.

Quantitative data show that temps give attention to preconditions for learning in the workplace to a greater degree than the regular personnel. Qualitative data suggest a need for a more effective organization of Social Interaction between regulars and temps. When it comes to Content, regulars are ascribed with a more all-embracing project and societal responsibility than temps and a need to have access to internal competences without procurement. Regulars are also attributed with a stronger Incentive for adoption of an overall perspective, while temps largely are perceived to stick to the formal mission statement.

\section{Discussion}

This study is about learning in terms of Social Interaction, Content, and Incentive among regular and temp personnel in a project organization. Learning in terms of competence transfer refers to preconditions that can be related to human resource planning a local organizational context 
with either positive or negative significance. The aim is to investigate whether the regulars and temps differ in their perceptions of these preconditions for learning and if there are some qualitative aspects that can be considered particularly significant in these differences.

The study is based on a case study with mixed methods in a government agency with a number of business areas (Yin, 1994). Data were collected via an online survey and individual interviews.

Analyses of quantitative data and thereof the answer on the first research question about potential differences between regulars and temps' perceptions of learning conditions in an inter-organizational based project organization, is that regulars are demanding preconditions for the Content dimension of learning to a greater extent than temps (see Table 1, cell 2). This is in line with Illeris (2007) definition of the Content dimension; learning is based on a "general dedication of the cultural and societal context which we are a part of" (p. 98). Obviously, the regulars are more integrated and rooted in the STA context, which may facilitate their learning in that respect. Also, Huckman and Pisano (2006) finds a critical aspect of context boundedness when surgeons moves between different organizational contexts. Analyses also indicate that temps pay attention to the Social Interaction and Incentive dimensions of learning to a higher degree than regulars (see Table 7). As the temps need to accommodate to new settings regularly and adopt to different work environments as they are changing workplaces they probably need to pay attention to the Social Interaction dimension of learning to a larger degree than regulars (see Table 1, cell 4).

The answers to the second research question about particularly significant qualitative aspects for the cooperation between regulars and temps are threefold. The analysis of qualitative data about Social Interaction shows regulars' interest in developing a professional environment that is characterized by context-bound competences and of an organization-wide consensus (see Table 1, cell 1). Furthermore, there are utterances of differentiation, showing that regulars are perceived to have their own area of responsibility, "their" organization, including colleagues and shared goals (see Table 1, cell 4). This is compared with temps, who mainly have their own interests, their specific tasks, and their specific assignment to complete (see Table 1 , cell 4). In addition, examples of socially constructed distinctions between the working conditions for the regulars and for the temps were found.

The results from the aspect of Content show that there are beliefs that emphasize the importance of certain competences that are stationed within the parent organization and that these competences also are filled with experiences from temps (see Table 1, cell 5). The competences that are especially expressed are overall societal perspective and internal tasks such as accounting and orders. In addition, this also emphasizes the importance of an effective com- munication and information network that includes temps. This view of competence can be linked to IPMA's (2015) understanding of individual competence, ie. individuals' knowledge and experience that they use to successfully carry out their duties in a particular organizational context.

The analysis of Incentive confirms that temps are found to perceive lower motives than regulars to take into account both the organizational and societal contexts (see Table 1, cell 9).

These findings suggest that human resource planning in terms of competence transfer between temps and regulars is not desirable in the STA. Similarly, the project owner, the STA, takes no responsibility for competence transfer between these staff groups. This responsibility is delegated to the individual project. In addition, valuable competences can to some extent be missing during the planning stages of a new project. In addition, temps tended to be more focused on their specific task, compared to regulars. These examples reflect the integration, differentiation, and fragmentation within the STA and its projects.

\subsection{Conclusions and implications}

Against this background, it is possible to draw the following three conclusions and implications. First, there is a difference between how regulars and temps pay attention to preconditions for learning. This conclusion is important to follow up for future research because it emphasizes partly in contrary to previous research, that competence transfer between regulars and temps are not satisfying, partly the risk that different personnel groups in the STA is likely to be divided into, on the one hand, thinkers/organizers and, on the other hand, performers/doers. If this happens, important practical skills fall outside of the organization, which in a metaphorical sense means that the hand is separated from the brain.

Second, temps express defects in the transfer of information due to temps not having the same organizational legitimacy in the STA. The conclusion implicates in contrary to previous research, that the project owner does not seem to take responsibility for any kind of competence or knowledge transfer between regulars and temps which entails the risk that temps may end up in an organizational vacuum where they neither have access to important information or the opportunity to share their skills. This can seriously weaken the organizational learning and job quality in STA.

Third, regulars are expected to embrace an organizational and social perspective on other terms than temps. This conclusion implicate the risk of a dequalification of temps ability to place their duties in an organizational and societal context, which in turn may lead to that others (the regulars) than the expert (the temp) on the performance of the work is responsible for the work content. This potential dequalification need to be followed up by future research 
because it indicates that STA's regular staff is not experts on their organization's core business. Instead, the expert (the temp) is located outside the STA, which can seem unfortunate for a tax-funded agency with such a strategically important national-wide function as STA.

Expressed on the basis of the analysis model in Table 1 , the results show a contradiction within the organization. Regulars' safeguarding a community or an organizational perspective, while temps are looking for their own good. This can be seen as evidence of the existence of a fragmented organizational background that regulars in the STA appears to be unreflective about. Regulars are demanding integration but experiences fragmentation. These results and implications are valid for the STA but we believe that they could also be relevant for other similar project-based organizations with temporary staff. Therefore, the scientific value of this paper is that using temps may result in or be a consequence of a fragmented organization. Thus, an implication is that organizations using temporary staff needs to take extra precaution in building a structure for competence transfer between temporary and regular staff.

It would be interesting to, in the future, study the consequences for competence transfer, as the disparate organizational legitimacy between regulars and temps in a project organization may affect the development of competences between and within individual projects under a parent organization. This also includes an analysis of temps' and regulars' (overall) societal and organizational perspective in the individual project organization. A final future research topic is to investigate the impact of a project in the planning stage that does not have access to necessary competences without previous procurement.

\section{Acknowledgement}

This work was supported by The Swedish Governmental Agency for Innovation Systems (VINNOVA) under Grant 2009-03060.

\section{Literature}

Argote, L., \& Fahrenkopf, E. (2016). Knowledge transfer in organizations: The roles of members, tasks, tools, and networks. Organizational Behavior and Human Decision Processes, 136, 146-159. http://doi. org/10.1016/j.obhdp.2016.08.003

Bakker, R. M. (2010). Taking Stock of Temporary Organizational Forms: A Systematic Review and Research Agenda. International Journal of Management Reviews, 12(4), 466-486. http://dx.doi.org/10.1111/ j.1468-2370.2010.00281.x

Bakker, R. M., Cambré, B., Korlaar, L., \& Raab, J. (2011). Managing the project learning paradox: A set-theoretic approach toward project knowledge transfer. Interna- tional Journal of Project Management, 29(5), 494503. http://dx.doi.org/10.1016/j.ijproman.2010.06.002

Bartsch, V., Ebers, M., \& Maurer, I. (2013). Learning in project-based organizations: The role of project teams' social capital for overcoming barriers to learning. International Journal of Project Management, 31(2), 239251. http://dx.doi.org/10.1016/j.ijproman.2012.06.009

Carlsson, S. A. (2003). Knowledge managing and knowledge management systems in inter-organizational networks. Knowledge and Process Management, 10(3), 194-206. http://dx.doi.org/10.1002/kpm.179

Cartwright, S., \& Gale, A. (1995). Project management: different gender, different culture? Leadership \& Organization Development Journal, 16(4), 12-16. https:// doi.org/10.1108/01437739510089058

Chen, J., Tong, L., \& Ngai, E. W. T. (2007). Inter-organizational knowledge management in complex products and systems: Challenges and an exploratory framework, Journal of Technology Management in China, 2(2), 134-144. http://dx.doi. org/10.1108/17468770710756077

Ellström, P.-E. (1992). Kompetens, utbildning och lärande i arbetslivet: problem, begrepp och teoretiska perspektiv [Competence, education, and learning in working life: problems, concepts, and theoretical perspective] (1. uppl.). Stockholm: Publica: Allmänna förl. distributör.

Ercikan, K., \& Roth, W-M. (2006) What Good Is Polarizing Research Into Qualitative and Quantitative? Educational Researcher, 35(5), 14-23. http://dx.doi. org/10.3102/0013189X035005014

Gale, A., \& Cartwright, S. (1995). Women in project management: entry into a male domain?: a discussion on gender and organizational culture. Leadership \& Organization Development Journal, 16(2), 3-8. https:// doi.org/10.1108/01437739510082262

Huckman, R. S., \& Pisano, G. P. (2006). The Firm Specificity of Individual Performance: Evidence from Cardiac Surgery. Management Science, 52(4), 473-488. http://doi.org/10.1287/mnsc.1050.0464

Illeris, K. (2007). Lärande [Learning] (2., rev. o.). Lund: Studentlitteratur.

Illeris, K. (2009). Competence, learning and education: how can competences be learned, and how can they be developed in formal education? In K. Illeris (Ed.), International perspectives on competence development: developing skills and capabilities (pp. 83-98). London; New York: Routledge.

Illeris, K. (2011). The fundamentals of workplace learning: understanding how people learn in working life. Milton Park, Abingdon, Oxon: Routledge.

IPMA. (2015). Individual Competence Baseline. (M. Sedlmayer, Ed.) (Version 4.). Zurich: International Project Management Association (IPMA). Retrieved from http://products.ipma.world/wp-content/up- 
loads/2016/03/IPMA ICB 4 0 WEB.pdf

Jonassen, D., \& Land, S. (2012). Preface. In D. Jonassen \& S. Land (Eds.), Theoretical foundations of learning environments (Second., pp. vii-x). New York: Routledge.

Lindgren, M., \& Packendorff, J. (2006). What's New in New Forms of Organizing? On the Construction of Gender in Project-Based Work. Journal of Management Studies, 43(4), 841-866. https://doi.org/10.1111/ j.1467-6486.2006.00613.x

Loewenthal, K. M. (2004). An introduction to psychological tests and scales. Hove, UK: Psychology Press.

Lundin, R. A., \& Söderholm, A. (1995). A theory of the temporary organization. Scandinavian Journal of Managment, 11(4), 437-455. http://dx.doi.org/10.1016/09565221(95)00036-U

Martin, J. (2002). Organizational culture. Mapping the terrain. Thousand Oaks, Calif.: SAGE.

Mertens, D. M. (2012) What comes First? The Paradigm or the Approach. Journal of Mixed Methods Research, 2(4), 255-57. http://dx.doi.org/10.1177/1558689812461574

Morgan, G. (2006). Images of organization. Thousand Oaks, Calif.: SAGE.

Mullaly, M. E. \& Thomas, J. (2010). Re-thinking project management maturity: perspectives gained from explorations of fit and value. Paper presented at PMI ${ }^{\circledR}$ Research Conference: Defining the Future of Project Management, Washington, DC. Newtown Square, PA: Project Management Institute.

Packendorff, J. (1995). Inquiring into the temporary organization: New directions for project management research. Scandinavian Journal of Management, 11(4), 319-333. http://dx.doi.org/10.1016/09565221(95)00018-Q

Pedhazur, E. J., \& Pedhazur Schmelkin, L. (1991). Measurement, design, and analysis: An integrated approach. New Jersey: Lawrence Erlbaum Associates.

Prencipe, A., \& Tell, F. (2001). Inter-project learning: processes and outcomes of knowledge codification in project-based firms. Research Policy, 30(9), 1373-1394. http://dx.doi.org/10.1016/S0048-7333(01)00157-3

Ragab, M. A. F., \& Arisha, A. (2013). Knowledge management and measurement: a critical review. Journal of Knowledge Management, 17(6), 873-901. http:// dx.doi.org/10.1108/JKM-12-2012-0381

Scarbrough, H., Swan, J., Laurent, S., Bresnen, M., Edelman, L., \& Newell, S. (2004). Project-Based Learning and the Role of Learning Boundaries. Organization Studies, 25(9), 1579-1600. http://dx.doi. org/10.1177/0170840604048001

Song, J., Almeida, P., \& Wu, G. (2003). Learning-by-Hir- ing: When Is Mobility More Likely to Facilitate Interfirm Knowledge Transfer? Management Science, 49(4), 351-365. http://doi.org/10.1287/mnsc.49.4.351.14429 STA. (2015a). Trafikverkets uppdrag [STA's mission]. Retrieved November 4, 2015, from http://www. trafikverket.se/om-oss/var-verksamhet/korta-fakta-om-trafikverket/

STA. (2015b). Vem gör vad av myndigheterna inom transportområdet? [Who is doing what among the authorities in the STA sector?] Retrieved November 4, 2015, from http://www.trafikverket.se/om-oss/var-verksamhet/korta-fakta-om-trafikverket/vem-gor-vad-avmyndigheterna/Vem-gor-vad-av-myndigheterna-inom-transportomradet/

Turner, R. J., \& Müller, R. (2003). On the nature of project as a temporary organization. International Journal of Project Management, 21, 1-8. http://dx.doi. org/10.1016/S0263-7863(02)00020-0

Van Wijk, R., Jansen, J. J. P., \& Lyles, M. A. (2008). Inter- and Intra-Organizational Knowledge Transfer: A Meta-Analytic Review and Assessment of its Antecedents and Consequences. Journal of Management Studies, 45(4), 830-853. http://dx.doi.org/10.1111/j.14676486.2008.00771.x

Wagner, S. M., \& Buko, C. (2005). An Empirical Investigation of Knowledge-Sharing in Networks. The Journal of Supply Chain Management, (November), 17-31. https://doi.org/10.1111/j.1745-493X.2005.04104003.X

Weick, K. E. (1995). Sensemaking in Organizations. (D. Whetten, Ed.) Foundation for Organizational Science. SAGE Publications.

Yin, R. K. (1994). Case study research: design and methods. Applied social research methods series, 5 (2. ed., p. xi, 171 p.). Thousand Oaks, CA: Sage.

Gunnar Augustsson (Ph.D.) is a Professor at the Department of Education, Mid Sweden University. He specializes in the study of inter-organizational relations, leadership, workplace learning, group relations and higher education. He teaches at all levels of education at the university.

Maria Rasmusson (Ph.D.) is a Senior Lecturer at the Department of Education, Mid Sweden University. She specializes in the study of large-scale assessments, quantitative analyses as well as reading and writing development with a special focus on digital reading. She teaches on undergraduate, graduate, and master level. 